\title{
Factors Affecting Callus Induction and Organogenesis in Saffron (Crocus sativus L.)
}

\section{Maryam Vahedi*, Siamak Kalantari and Seyed Alireza Salami}

Department of Horticultural Science, Faculty of Agricultural Sciences and Engineering, College of Agriculture \& Natural Resources, University of Tehran, Karaj, Iran

Key words: Saffron, Growth regulators, Callogenesis, Commercial production

\begin{abstract}
Saffron (Crocus sativus L.) belongs to Iridaceae and is known an important native commercial plants in Iran for its high value of saffron. The best growth regulator composition for callus production from corms and sahoot regeneration from callus were determined. Saffron corms harvested from previous crops are generally used for future cropping cycles. However, this practice causes major yield losses due to the heavy attack by different pathogens. Availability of healthy disease free planting materials is of great importance for successful cultivation of saffron. By this investigation the best composition of growth regulators for callus production from corms and shoot regeneration from callus were determined. Callus induction of Crocus sativus L. was investigated by using different combinations NAA, 2, 4-D and TDZ, BA and Kn. The highest frequency of callus induction was observed in medium containing $2 \mathrm{mg} / \mathrm{l} 2$, 4-D + $1 \mathrm{mg} / \mathrm{l} \mathrm{BA}$ followed by $1 \mathrm{mg} / 1$ 2, 4-D + $0.15 \mathrm{mg} / \mathrm{l} \mathrm{Kn}$. However, in case of growth parameters such as diameter and the area of calli the best result was obtained in the medium supplemented with $2 \mathrm{mg} / 1$ 2, 4-D + $1 \mathrm{mg} / \mathrm{l} \mathrm{BA}$. In some treatments, calli were transferred to organogenesis stage after two subcultures. For sprouting of shoots transferred to medium containing $1 \mathrm{mg} / \mathrm{l} \mathrm{BAP}$ and $1 \mathrm{mg} / \mathrm{l} \mathrm{NAA}$. Statistical analyses indicated that the treatment containing $5 \mathrm{mg} / \mathrm{l} \mathrm{NAA}$ and $5 \mathrm{mg} / \mathrm{l} \mathrm{TDZ}$ proved to be the best growth regulator treatment for shoot regeneration from the saffron calli.
\end{abstract}

\section{Introduction}

Saffron (Crocus sativus L.) is one of the most important crops cultivated in the temperate regions of several countries of the world as an high value spice. Iran is the largest producer of saffron in the world. Saffron spice obtained from the dried floral stigmas, is the most valuable commodity harvested since ancient

*Author for correspondence: <mary.vahedi@gmail.com>. 
times for its odoriferous, coloring, and medicinal properties (Plessner and Ziv 1999). Saffron production and its breeding are mainly hampered by sterility caused by triploidy. It is asexually propagated through corms thus remained main source of planting saffron (Mathew 1982). Vegetatively propagated saffron corms harbor many insect pests and pathogens. Pathogens like bacteria, fungi and viruses remain active after the corms are harvested for planting and become the major source of pathogen distribution contributing to major crop losses. Sanitary measures and corm treatments failed to successfully control these pathogens. Bactericides and fungicides can be used to control these pathogens but such measures add to the high cost of production and environmental pollution. Viral infections are the most difficult to control in the absence of any known effectual treatment (Katoch et al. 2003). Saffron crops suffer uniformity with a low yield due to low quality planting material. In this backdrop saffron propagation through tissue culture offers a great potential for the production of pathogen-free high quality propagation materials (Debergh and Read 1991, De Hertogh 1996). Traditionally, saffron is cultivated by planting the corms of previous growing season. Since different pathogens attack saffron corms, they cause rotting, necrosis, reduce growth considerably and delay in flowering (Fernández and Pandalai 2004). Further invasion of pathogens results in the reduction in flowering and consequential low yield each year. It is, therefore evident that planting of infected corms would result in marked yield reduction in the newly established or re-planted farms. Finding of a suitable method to produce pathogen-free corms and supply them rapidly and efficiently can reduce this problem, thereby enhancing the yield. Tissue culture is fast, offering a largescale propagation of pathogen-free healthy plants (Draget et al. 1988). By using MS and right growth regulator combinations, Ting et al. (1979) induced callus formation and successfully regenerated plantlets from the calli (Ebrahimzadeh et al. 2000a, Ilahi et al. 1987, Isa et al. 1990).

Saffron corm propagation can also be achieved through indirect organogenesis originating from an intervening callus phase. Direct and indirect corm propagation induced through the utilization of growth regulator combinations such as auxins and cytokines (Yildirim 2007, Plessner et al. 1989). Plessner et al. (1989) utilized saffron corms for plantlet regeneration reported cytokinin and auxin were essential for regular development. Indirect organogenesis from callus cultures have been reported by (Ilahi et al. 1987). Callus was induced through different combinations of growth regulators. Micropropagation of Crocus has been reviewed by Plessner and Ziv (1999), Bagheri and Vesal (2006). Ding et al. (1981) were the first to report successful tissue culture of Crocus. They successfully produced callus which regenerated 
into intact plantlets from corm explants, when the culture medium was supplemented with IAA and 2, 4-D. By using a similar medium, Ilahi et al. (1987) produced callus using corm explants. The resulting callus pieces differentiated into buds. Schenk and Hildebrandt (1972) reported the importance of the medium composition e.g., the role of growth regulators for induction of callus and their subsequent regeneration into plantlets.

The present study reports successful regeneration and production of tissue culture derived plants from saffron through corm micropropagation via callus induction.

\section{Material and Methods}

The corms of saffron (a perennial autotriploid, sterile and vegetatively propagated plant) were collected from a local farm located in Nishapur (Korasan province), Iran. Corms were thoroughly washed with tap water and outer layers were removed, washed with running water and immersed in dishwashing liquid for half an hour and subsequently treated for $10 \mathrm{~min}$ in Hygen (benzalconium chloride $1 \%$ ) and rinsed thoroughly with tap water. Corms explants were finally incubated in $70 \%$ ethanol for $4 \mathrm{~min}$ and $20 \%$ commercial bleach containing $1 \%$ sodium hypochlorite for $15 \mathrm{~min}$ and rinsed thrice in sterile distilled water.

Dried corms were then prepared and cut into rectangular sections from the central meristematic region of each corm and used as explants. Explants were then cultured on basal medium supplemented with 3\% sucrose. The medium was solidified with $0.7 \%$ agar and cultures were incubated in a growth chamber under dark conditions at $25^{\circ} \mathrm{C}$ for callus induction. Different growth regulator combinations were tested for callus induction (Table 2) as suggested by Sheibani et al. (2007), Darvishi et al. (2007), Majourhay et al. (2007), Sharifi and Ebrahimzade (2010), Blazquez et al. (2009).

First calli were observed after 45 days and were subcultured twice on the same callus induction medium after one month. Some calli showed shoot formation and at this stage all callus cultures were transferred to a new shoot induction medium containing NAA $(1 \mathrm{mg} / \mathrm{l})$ and BAP $(1 \mathrm{mg} / \mathrm{l})$ as suggested by (Vatankhah et al. 2010). Shoots were multiplied in this medium for two subcultures of one month each. Plantlets were then transferred to jars for rooting and subsequently for hardening and planting.

A completely randomized design was used. Five replicates each with five meristem pieces were used for each treatment. Percentage of callogenesis was recorded after eight weeks of culturing. Effects of different growth regulator combinations (Table 2) on lateral meristems callogenesis were investigated. 
Heights of calli were recorded on a scale of (0- none, 1- medium, 2- high). Average calli diameter was determined based on the average of the longest width and length of calli; the rate of calli growth index was calculated by multiplying the average diameter and height of calli as suggested by (Taylor and Secor 1992).

\section{Results and Discussion}

Callus initiation was observed from lateral meristem after 45 days of inoculation. Effects of different growth regulator combinations were studied on callusing, callus height, callus diameter and callus area (Tables 1 and 2). All combinations were used successfully to induce callus. However, different plant growth regulators had significantly different effects on various characteristics of the callus growth. For example, the highest callus percentage observed ranged from 72 - 76 (Table 2). Growth regulators in the combination of $1 \mathrm{mg}$ of 2,4-D and $0.15 \mathrm{mg} / \mathrm{l} \mathrm{Kn}$ yielded the highest callus (76\%) followed by BA and 2,4-D (Raja et al. 2006) and the lowest percentage (36) was observed when TDZ was used. Similar was the case with other callus growth factors (Table 2). Low callus percentage induction was observed using TDZ contradicted Schenk and Hildebrandt (1972) findings, reported TDZ as a very effective growth regulator for somatic embryogenesis and organogenesis in different plant species. Shoot formation was successfully induced in 4 out of 7 treatments i.e. 1, 3, 4 and 5, respectively (Fig. 2). Three treatments failed to propduce any shoots where the growth regulator combinations including $\mathrm{Kn}+2,4-\mathrm{D}$ with different concentrations and TDZ $+2,4-\mathrm{D}$ were used. Even though the highest callusing rate was observed from combination of $\mathrm{Kn}+2,4-\mathrm{D}$, calli failed to produce shoots. It was concluded that the best growth regulator combination for high quality callus induction and shoot formation was 2,4-D (1 mg/l $)+$ BA $(0.15 \mathrm{mg} / \mathrm{l})$. Calli produced on different combinations of growth regulators behaved differently in case of morphological characters (Table 1). Although the growth rate of calli was high with the hormonal treatment of $(2,4-\mathrm{D}+\mathrm{Kn})$ calli induced by these treatments were compact and nodular, and light brown in color. Brownish soft friable calli were produced by 2,4-D + BA and glassy yellowish calli were observed from TDZ and NAA + TDZ. A very slow growing compact callus was observed in 2,4-D + TDZ. Shoot regeneration could significantly be affected by the quality of calli. A light brown calli produced high shoot regeneration and low rate was observed in case of glassy calli.

It has been recommended that incubation temperature could also significantly affect shoot regeneration from calli and somatic embryos. Isa et al. (1990) had previously reported the positive effect of lower temperatures on the 
regeneration of plantlets from embryogenic and non-embryogenic calli from domestic saffron (Isa et al., 1990; Ebrahimzadeh et al. 2000b). A low temperature of $20 \pm 2{ }^{\circ} \mathrm{C}$ or less has been recommended for high rate of shoot regeneration in saffron. It seemed reasonable to incubate callus cultures at temperature below $25^{\circ} \mathrm{C}$ to achieve high shoot formation. Shoots were successfully regenerated from calli when cultured on medium containing NAA and BAP (Figs 2 and 3).

Table 1. Morphological characteristics of calli produced on the medium supplemented with different combinations of growth regulators in saffron.

\begin{tabular}{ll}
\hline Growth regulators & Morphology of calli \\
\hline $2,4-\mathrm{D}+\mathrm{BA}$ & Brownish, soft and friable \\
$2,4-\mathrm{D}+\mathrm{Kn}$ & Compact and nodular \\
TDZ & Glassy with growing buds \\
$\mathrm{NAA}+\mathrm{TDZ}$ & Glassy with growing yellowish buds \\
2,4-D+ TDZ & Very slow growing compact callus \\
\hline
\end{tabular}
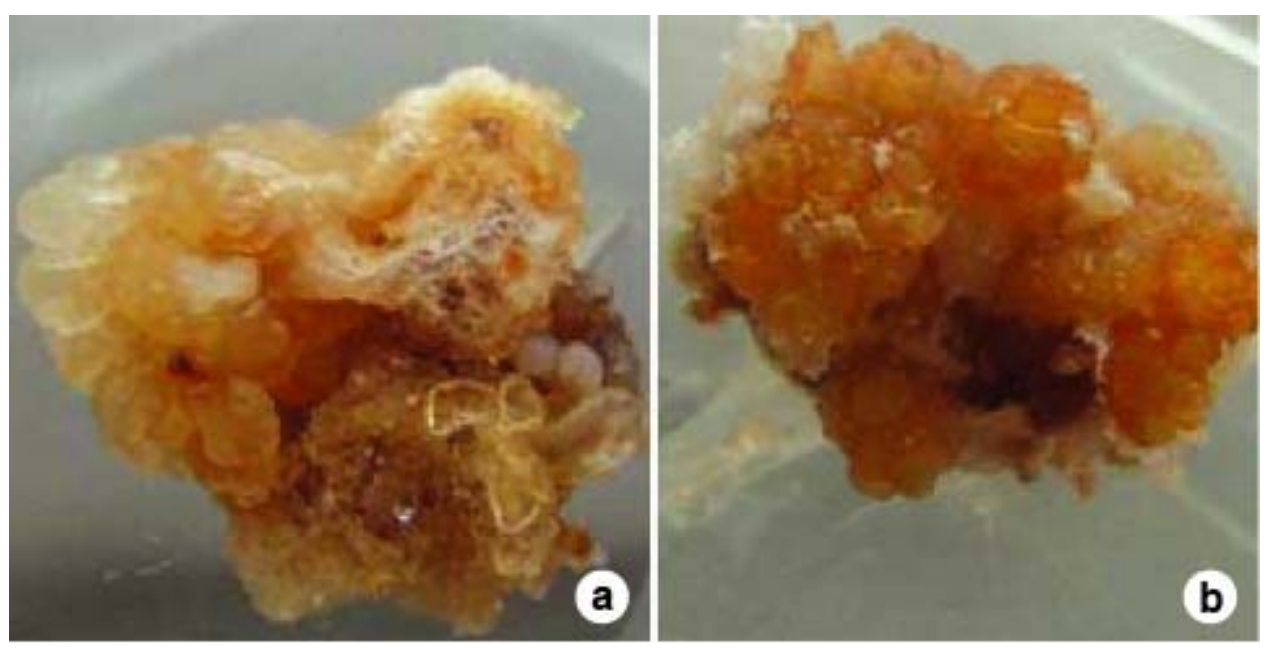

Fig. 1. Effects of different growth regulator combinations on callus induction in saffron from corm meristem cultures. Two growth regulator combinations produced the highest callus percentage (a) 2,4-D (2 mg/l) + BA $(0.1 \mathrm{mg} / \mathrm{l})$, (b) 2,4-D (1 mg/l) + Kn $(0.15 \mathrm{mg} / \mathrm{l})$.

Ilahi et al. (1987) reported that callus could be differentiated into shoots on the medium containing both NAA and BAP as also suggested by (Yildirim 2007). Similarly, the effects of different sugar concentrations on callus induction and shoot regeneration have also been reported (Sharma et al. 2008) therefore deemed future investigations. 

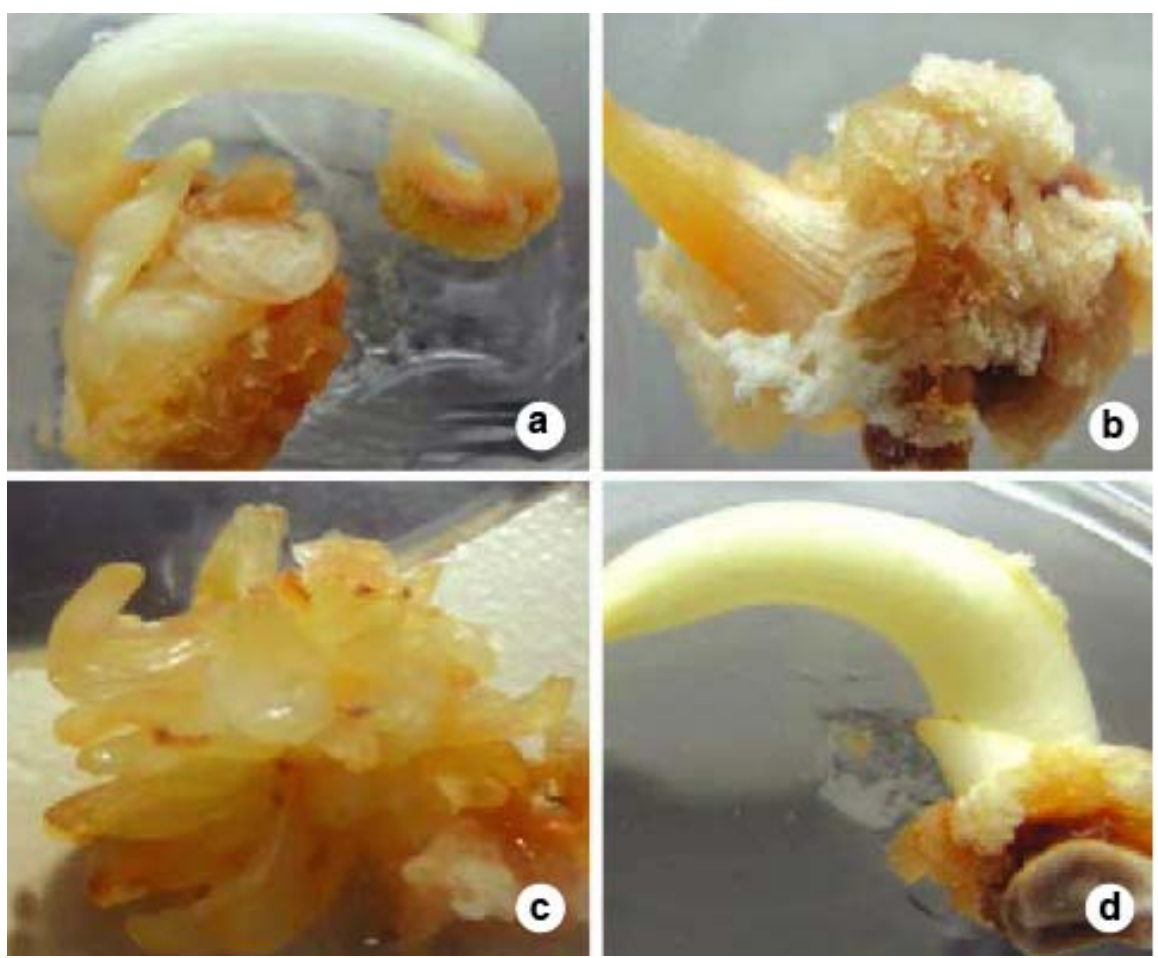

Fig. 2. Shoots regenerated through callus on the medium consisting of four treatments (1, 3,4 and 5) transferred to the medium containing NAA $(1 \mathrm{mg} / \mathrm{l})+\mathrm{BAP}(1 \mathrm{mg} / \mathrm{l})$ for sprouting.

Table 2. Effects of different growth regulator combinations and concentrations on callusing, callus height, callus diameter and callus area from lateral meristems of saffron.

\begin{tabular}{clrlll}
\hline $\begin{array}{c}\text { Treatment } \\
\text { number }\end{array}$ & $\begin{array}{l}\text { Growth } \\
\text { regulators }\end{array}$ & $\begin{array}{c}\text { Callusing } \\
(\%)\end{array}$ & $\begin{array}{l}\text { Callus } \\
\text { height }\end{array}$ & $\begin{array}{l}\text { Callus } \\
\text { diam. (cm) }\end{array}$ & $\begin{array}{l}\text { Callus } \\
\text { area }\end{array}$ \\
\hline 1 & $0.1(2,4-\mathrm{D})+2(\mathrm{BA})$ & $56 \pm 9.80 \mathrm{abc}$ & $1.1 \pm 0.19 \mathrm{abc}$ & $1.23 \pm 0.10 \mathrm{~b}$ & $1.4 \pm 0.30 \mathrm{bc}$ \\
2 & $1(2,4-\mathrm{D})+0.15(\mathrm{Kn})$ & $76 \pm 7.48 \mathrm{a}$ & $1.3 \pm 0.20 \mathrm{ab}$ & $1.52 \pm 0.08 \mathrm{~b}$ & $1.99 \pm 0.36 \mathrm{~b}$ \\
3 & $1(\mathrm{TDZ})$ & $36 \pm 4.00 \mathrm{c}$ & $0.5 \pm 0.22 \mathrm{c}$ & $0.72 \pm 0.12 \mathrm{c}$ & $0.445 \pm 0.23 \mathrm{~d}$ \\
4 & $0.5(\mathrm{TDZ})$ & $52 \pm 8.00 \mathrm{bc}$ & $0.7 \pm 0.20 \mathrm{bc}$ & $0.87 \pm 0.15 \mathrm{c}$ & $0.72 \pm 0.24 \mathrm{~cd}$ \\
5 & $5(2,4-\mathrm{D})+1(\mathrm{TDZ})$ & $40 \pm 6.32 \mathrm{c}$ & $0.7 \pm 0.20 \mathrm{bc}$ & $0.66 \pm 0.09 \mathrm{c}$ & $0.45 \pm 0.14 \mathrm{~d}$ \\
6 & $5(\mathrm{NAA})+1(\mathrm{TDZ})$ & $72 \pm 4.90 \mathrm{ab}$ & $1.3 \pm 0.20 \mathrm{ab}$ & $1.45 \pm 0.09 \mathrm{~b}$ & $1.865 \pm 0.27 \mathrm{~b}$ \\
7 & $0.1(\mathrm{BA})+2(2,4-\mathrm{D})$ & $76 \pm 4.00 \mathrm{a}$ & $1.7 \pm 0.20 \mathrm{a}$ & $1.88 \pm 0.12 \mathrm{a}$ & $3.135 \pm 0.30 \mathrm{a}$ \\
\hline
\end{tabular}

This study demonstrated a large number of disease free high quality plantlets could be produced in a short period of time. Combination of different growth regulators have significantly different effects on callus induction and 
shoot regeneration in saffron. It is, therefore, concluded that for high shoot regeneration, use of the right combination of growth regulators, media composition and incubation conditions is necessary.
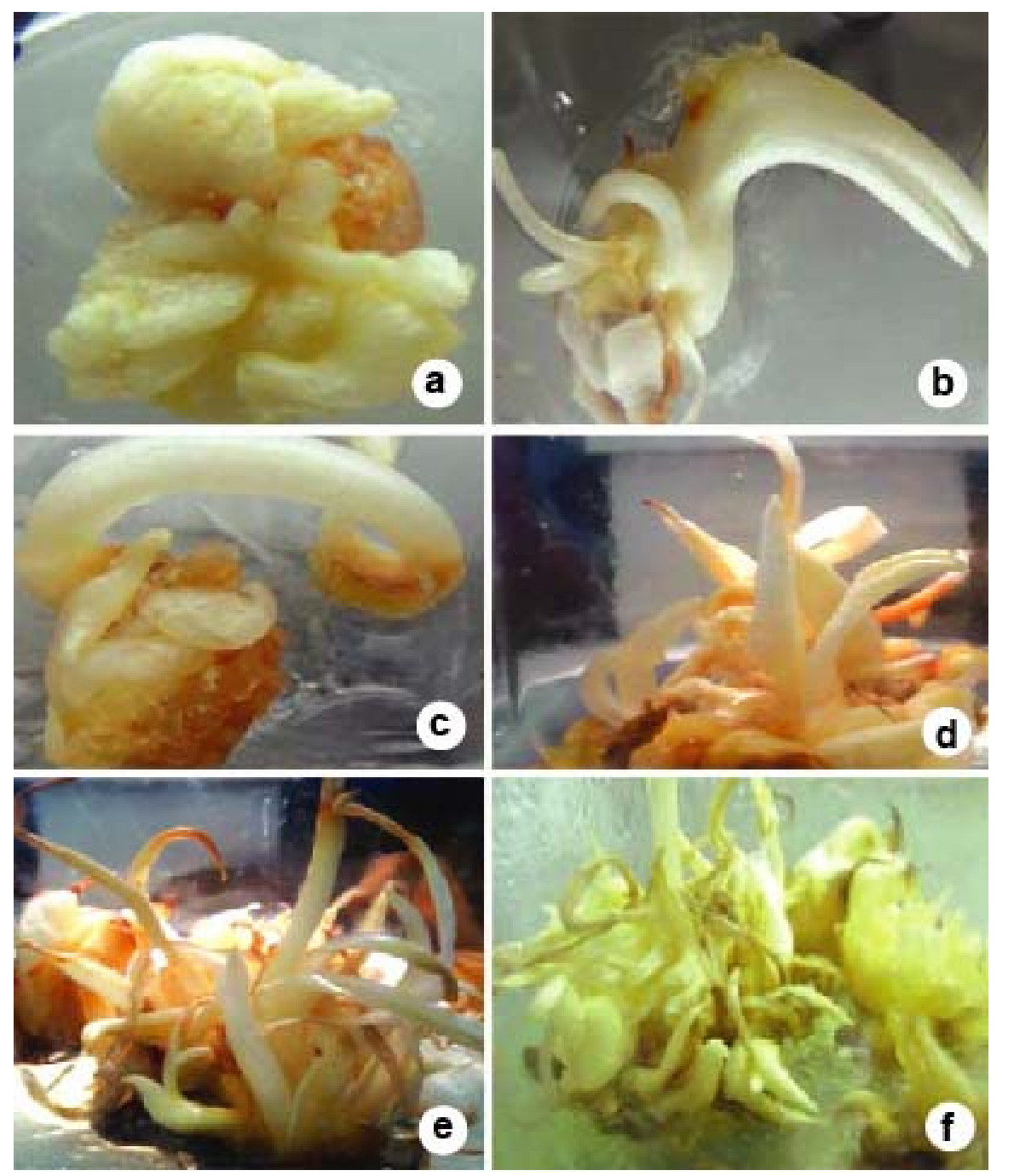

Fig. 3. Different stages of shoot regeneration in saffron from callus induction to cormlet production. (a) Callus was inducted on the medium supplemented with NAA (5 $\mathrm{mg} / \mathrm{l})+\mathrm{TDZ}(1 \mathrm{mg} / \mathrm{l})$, (b) shoot emergence after one subculturing on the same medium, (c) multiple shoots formed after two subculturing on the same medium, (d) regenerated shoots when transferred into the medium containing NAA $(1 \mathrm{mg} / \mathrm{l})+$ BAP $(1 \mathrm{mg} / \mathrm{l})$, (e) shoot formation and cormlet production after two months and (f) elongated and well formed shoots after three months. 


\section{Acknowledgement}

This work was a part of M.Sc. thesis completed at the Department of Horticultural Sciences, Agricultural Science \& Engineering faculty, University of Tehran. Authors wish to thank and appreciate all collaborations received from technicians during the course of this study.

\section{References}

Bagheri A and Vesal SR (2006) Genetics, sterility, propagation and in vitro production of secondary metabolites. In: Kafi M, Koocheki A, Rashed MH, Nassiri M (Eds.) Saffron (Crocus sativus): Production and Processing. Sci. Publi., Plymouth, England, pp. 119-137.

Blazquez S, Olmos E, Hernández JA, Fernández-García N, Fernández JA and Piqueras A (2009) Somatic embryogenesis in saffron (Crocus sativus L.). Histological differentiation and implication of some components of the antioxidant enzymatic system. Plant Cell, Tiss. and Org. Cult. 97(1): 49-57.

Darvishi E, Zarghami R, Mishani CA and Omidi M (2007) Effects of different hormone treatments on non-embryogenic and embryogenic callus induction and timed enzyme treatments on the number and viability of isolated protoplasts in saffron. (Crocus sativus L.). Acta Hortic. 739: 279-284.

Debergh PC and Read PE (1991) Micropropagation. In: Micropropagation Technology and Applications. Debergh, PC and Zimmerman, RH (Eds.) Kluwer Acad. Pub. Dordrecht. pp. 1-13.

De Hertogh AA (1996) Holland Bulb Forcer's Guide. 5th edition, Intl. Flower Bulb Centre, Hillegom, The Netherlands.

Ding B, Bai SH, Wu and Fang XP (1981) Induction of callus and regeneration of plantlets from corms of Crocus sativus L. Acta botanica Sinica 23: 419-420.

Draget KI, Myhre S and Østgaard K (1988) Regeneration, cultivation and differentiation of plant protoplasts immobilized in Ca-alginate beads. J. Plant Physiology 132(5): 552556.

Ebrahimzadeh H, Rajabian T and Karamian R (2000a) In vitro production of floral buds and stigma-like structures on floral organ of Crocus sativus L. Pak. J. Bot. 32: 134-150.

Ebrahimzadeh H, Karamian R and Nori-Daloii MR (2000b) Shoot regeneration from saffron protoplasts immobilized in Ca-alginate beads. J. Sciences Islamic Republic of Iran 11: 69-72.

Fernández, JA and Pandalai SG (2004) Biology, biotechnology and biomedicine of saffron. Recent Research Developments in Plant Science 2: 127-159

Ilahi I, Jabeen M and Firdous N (1987) Morphogenesis with saffron tissue cultures. J. Plant Physiol. 128: 227-232.

Isa T, Orgasawara T and Kaneko H (1990) Regeneration of saffron protoplasts immobilized in Ca-alginate beads. Japan. J. Breed. 40(2):153-157.

Katoch, M, Abdin, MZ, Ram R and Zaidi AA (2003) An overview of diagnostics for viruses infecting gladiolus. Crop Protection 22(1):153-156. 
Majourhay K, Ferna'ndez JA, Marti nez-Go'mez P and Piqueras A (2007) Enhanced plantlet regeneration from cultured meristems in sprouting buds of saffron corms. Acta Hortic. 739: 275-278.

Mathew B (1982) The Crocuses. B.T. Batsford, London.

Plessner O and Ziv M (1999) In vitro propagation and secondary metabolite production in Crocus satious L. In: Negbi M (Ed.) Medicinal and aromatic plants - industrial profiles. Harwood Academic Publishers, Amsterdam, Netherlands, pp. 137-148.

Plessner O, Negbi M, Ziv M and Basker D (1989) Effects of temperature on saffron crocus (Crocus sativus L.): induction of hysteranthy. Israel J. Bot. 38: 1-7.

Raja W, Zaffer G and Wani SA (2006) In vitro microcorm formation in saffron (Crocus sativus L.). In: II International Symposium on Saffron Biology and Technology 739: 291-296.

Sharma KD, Rathour R, Sharma R, Goel S, Sharma TR and Singh BM (2008) In vitro cormlet development in Crocus sativus. Biol. Plantarum 5: 709-712.

Schenk RU and Hildebrandt AC (1972) Medium and techniques for induction and growth of monocotyledonous and dicotyledonous plant cell cultures. Can. J. Bot. 50: 199-204.

Sharifi G and Ebrahimzadeh H (2010) Changes of antioxidant enzyme activities and isoenzyme profiles during in vitro shoot formation in saffron (Crocus sativus L.). Acta Biologica Hungarica 61(1): 73-89.

Sheibani M, Nemati SH, Davarinejad GH, Azghandi AV and Habashi AA (2007) Induction of somatic embryogenesis in saffron using thidiazuron (TDZ). Acta Hortic. 739: 259-268.

Taylor RJ and Secor GA (1992) Average tissue diameter as a non-destructive determinant of potato protoplast-derived callus growth. Environmental and Experimental Botany 32(1): 43-48.

Ting, PT, Pai SH, Wu I and Wang PK (1979) Preliminary report on tissue culture of corm of Crocus sativus L. Acta Botanica Sinica 21: 387-387.

Vatankhah E, Niknam V and Ebrahimzadeh H (2010) Activity of antioxidant enzyme during in vitro organogenesis in Crocus sativus. Biologia Plantarum 54(3): 509-514.

Yildirim E (2007) Development of in vitro micropropagation techniques for saffron (Croscus sativus L.). Ph.D. Thesis. Middle East Technical University. 